\title{
Identifikasi Non Value Added Activity Melalui Activity-Based Management Untuk Meningkatkan Efisiensi Hotel Travello Manado
}

\author{
Irna Prisye Daleno \\ David Paul Elia Saerang \\ Inggriani Elim
}

\author{
Fakultas Ekonomi, Jurusan Akuntansi \\ Universitas Sam Ratulangi \\ Email : irnaprisye@gmail.com
}

\begin{abstract}
ABSTRAK
Menghadapai era globalisasi yang penuh dengan persaingan ketat, perusahaan harus dapat meningkatkan kinerja dan kemampuan beradaptasi terhadap lingkungan yang ada untuk dapat terus bersaing. Persaingan ini tidak hanya terjadi di lingkungan industri manufaktur saja tetapi juga industri jasa. Seiring dengan meningkatnya persaingan di bidang industri jasa khususnya perhotelan, maka Hotel Travello Manado harus menciptakan suatu keunggulan kompetitif dibanding pesaingnya. Oleh karena itu untuk menciptakan keunggulan tersebut, Hotel Travello Manado harus dapat menciptakan efisiensi dengan cara mengelola aktivitas yang dilakukan tanpa mengurangi kualitas pelayanan yang diberikan kepada pelanggan. Metode yang digunakan untuk mengelola aktivitas sehingga tercipta efisiensi ini disebut Activity-Based Management.Penelitian dilakukan pada divisi room Hotel Travello Manado. Penelitian yang dilakukan bersifat deskriptif yaitu dengan cara menganalisa semua aktivitas yang ada di divisi room Hotel Travello Manado lalu mengklasifikasikan aktivitas tersebut menjadi aktivitas bernilai tambah dan tidak bernilai tambah. Aktivitas tidak bernilai tambah ini akan dieliminasi ataupun digabungkan dengan aktivitas lain yang sejenis sehingga biaya tidak bernilai tambah yang muncul dari aktivitas ini dapat direduksi jumlahnya. Data yang digunakan pada penelitian ini yaitu data kuantitatif berupa laporan biaya divisi room Hotel Travello Manado tahun 2012 dan data kualitatif seperti sarana dari hotel tersebut.Kesimpulan dari penelitian ini yaitu dengan menerapkan metode Activity-Based Management, Hotel Travello Manado melakukan pengurangan biaya tidak bernilai tambah sehingga hal ini dapat menciptakan efisiensi tanpa harus mengurangi kualitas pelayanan yang diberikan pihak Hotel Travello Manado kepada para pelanggan, dan dengan menggunakan Activity-Based Management maka total biaya di divisi room dapat berkurang sebanyak Rp. 176.226.624,08 dari Rp. 3.576.508.933,00 menjadi Rp. 3.400.282.308,92
\end{abstract}

\section{Kata kunci : $\quad$ Manajemen Berdasarkan Aktivitas, Aktivitas Tidak Bernilai Tambah ABSTRACT}

Faced with the globalization era filled with fierce competition, companies must be able to improve the performance and adaptability to the existing environment to be able to continue to compete. The rivalry does not happen in manufacture industry environmentbut also in service industry, with increasing the competition in service industry especially in hotel, so Travello Hotel should create a competitive excellence. Therefore to create that excellence, Travello Hotel should has efficiency with the way to manage the activity without cutdown the quality of service that give to customer. This method use to manage the activity, so that create this efficiency is calledActivity-Based Management.The research has done in room division of Manado Travello Hotel. The research is descriptive which analyze to all activity in room division of Travello Hotel and classify that activity to be value added activity and non value added activity. The value added activity will be eliminated or combined with the other activity that is similar, so that the value added non cost appear from this activity could reduced the amount. The data that used in this research is quantitative as cost report in room division in 
Travello Hotel tahun 2012 and the qualitative data is like tool from the Hotel.The conclusion this research is to apply the method of activity-basedManagement, Travello Hotel reduces the non value added cost so it can create afficiency without cutdown the quality of service the given from Travello Hotel to customer, with using the activity-based management,the totally of expense in room division are decreases as much as Rp. 176.226.624,08 from Rp. 3.576.508.933,00 to be Rp. 3.400.282.308,92.

\title{
Keywords : Activity-Based Management, Non Value Added Activity PENDAHULUAN
}

\section{Latar Belakang}

Menghadapai era globalisasi yang penuh dengan persaingan ketat, perusahaan harus dapat meningkatkan kinerja dan kemampuan beradaptasi terhadap lingkungan yang ada untuk dapat terus bersaing. Dengan adanya kemajuan yang sangat pesat pada dunia usaha tersebut akan mendorong perekonomian, baik di tingkat nasional maupun internasional untuk menuju era perdagangan bebas, yang tentu saja hal tersebut akan berdampak pada peningkatan persaingan bisnis yang semakin ketat. Peningkatan persaingan ini tidak hanya terjadi di bidang industri barang/produk saja melainkan juga telah merambah pada industri jasa, khusunya pada usaha perhotelan.

Hotel merupakan suatu bentuk badan usaha yang bergerak di bidang jasa penginapan yang dikelola secara komersial dan memerlukan pengelolaan secara profesional terhadap sumber dana dan sumber daya manusia dalam menghasilkan jasa dengan biaya yang efisien. Keberhasilan dari industri jasa ini dapat dinilai dari kepuasan pelanggan yang menggunakan jasa tersebut efisiensi biaya.

Biaya merupakan akibat dari adanya aktivitas yang dilakukan untuk menghasilkan barang atau jasa. Efisiensi biaya tercapai jika biaya yang dikeluarkan dalam aktivitas menghasilkan produk atau jasa merupakan biaya yang benar-benar dibutuhkan untuk menghasilkan produk atau jasa tersebut sehingga yang perlu ditangani dan dikelola oleh manajemen bukanlah biaya yang terjadi, melainkan aktivitas-aktivitas yang terjadi dalam kegiatan operasional hotel agar tidak terjadi pemborosan biaya. Perusahaan jasa perhotelan memerlukan informasi akuntansi manajemen yang akurat, relevan, dan tepat waktu. Penerapan activity-based management mampu membantu perusahaan perhotelan memperoleh informasi yang relevan dan sistem manajemen biaya yang baru ini juga mampu berperan dalam meningkatkan keakuratan pengendalian biaya.

Peneliti ingin mengetahui bagaimana salah satu hotel berbintang seperti Hotel Travello Manado dapat mengidentifikasikan aktivas-aktivitas melalui Activity-based management untuk melakukan pengurangan biaya aktivitas serta meningkatkan kualitas pelayanan yang diberikan kepada pelanggan.

\section{Tujuan Penelitian}

Membantu pihak manajemen hotel untuk dapat melakukan pengefisiensian biaya yang muncul melalui pengidentifikasian aktivitas tidak bernilai tambah tersebut.

\section{TINJAUAN PUSTAKA}

\begin{abstract}
Akuntansi
Menurut Horngren dan Harrison (2007:4) , "Akuntansi adalah sistem informasi yang mengukur aktivitas bisnis, memproses data menjadi laporan, dan mengkomunikasikan hasilnya kepada pengambil keputusan. Rudianto (2009:14) mengatakan bahwa akuntansi adalah aktivitas mengumpulkan, menganalisis, menyajikan dalam bentuk angka, mengklasifikasikan, mencatat, meringkas dan melaporkan aktivitas atau transaksi perusahaan dalam bentuk informasi keuangan.
\end{abstract}

\section{Manajemen Berdasarkan Aktivitas (Activity-Based Management)}


Hansen dan Mowen (2009:224) mendefinisikan Activity-Based Management adalah sebagai pendekatan untuk keseluruhan sistem yang terintegrasi dan berfokus pada perhatian manajemen atas berbagai aktivitas dengan tujuan meningkatkan nilai bagi pelanggan dan laba yang dicapai dengan mewujudkan nilai ini tersebut.

Hilton et al (2006:180) mendefinisikan manajemen berdasarkan aktivitas digunakan oleh manajemen untuk mengevaluasi biaya dan nilai-nilai dari kegiatan proses untuk mengidentifikasi peluang untuk peningkatan efisiensi.

\section{Keunggulan dan Manfaat Activity-Based Management (ABM)}

Blocher et al (2011:132) menjelaskan 2 keunggulan ABM yaitu, (1) Activity-Based Management mengukur efektivitas proses dan aktivitas bisnis kunci dan mengidentifikasi bagaimana proses dan aktivitas tersebut bisa diperbaiki untuk menurunkan biaya dan meningkatkan nilai bagi pelanggan. (2) Activity-Based Management memperbaiki fokus manajemen dengan cara mengalokasikan sumber daya untuk menambah nilai aktivitas kunci, pelanggan, dan metode untuk mempertahankan keunggulan bersaing perusahaan.

Supriyono (2008:343) menjelaskan ABM dapat menyediakan alat bagi manajemen untuk meningkatkan profitabilitas dan kinerja pada berbagai level organisasi.

Tunggal (2010:73), menjelaskan beberapa manfaat dari Activity-Based Management adalah: (1) Menyediakan suatu cara untuk proses berkesinambungan. (2) Memfokuskan pada biaya-biaya penting. (3) Menciptakan suatu hubungan antara biaya-biaya bisnis dan menciptakan nilai. (4) Menyediakan ukuran-ukuran non keuangan. (5) Menyertakan semua fungsi bisnis dalam suatu organisasi. (6) Mengakui peran perubahan perilaku dalam sistem pelaporan.

\section{Aktivitas Bernilai Tambah (Value Added Activity)}

Hansen dan Mowen (2009:383) mengemukakan aktivitas bernilai tambah adalah yang diperlukan untuk tetap dalam bisnis.

Miller (2008:7) menjelaskan aktivitas bernilai tambah adalah kegiatan yang dinilai berkontribusi terhadap nilai pelanggan atau memuaskan kebutuhan organisasi.

\section{Aktivitas Tak Bernilai Tambah (Non Value Added Activity)}

Hansen \& Mowen (2009:384) mengemukakan aktivitas tak bernilai tambah adalah semua kegiatan lain diluar kegiatan-kegiatan bisnis yang tidak penting dan karena itu tidak diperlukan.

Miller (2008:7) menjelaskan aktivitas tak bernilai tambah merupakan kegiatan yang dianggap tidak memberikan kontribusi terhadap nilai pelanggan atau kebutuhan organisasi itu.

\section{Efisiensi}

Mulyadi (2005 : 378) mengemukakan bahwa efisiensi merupakan rasio antara keluaran dan masukan suatu proses, dengan fokus perhatian pada konsumsi masukan.

\section{Penelitian Terdahulu}

Penelitian ini juga mengacu pada penelitian sebelumnya yang dilakukan oleh Fariyani (2012) dengan judul penelitian "Efisiensi Biaya Produksi dengan Metode Activity-Based Management (Studi Kasus Perusahaan Khalis Shoes)". Penelitian ini bertujuan untuk mengetahui pelaksanaan Activity Based Management (ABM) pada industri perdagangan, yaitu industri sepatu, untuk mengetahui Activity Based Management (ABM) yang diterapkan mampu mendorong efisiensi biaya produksi atau tidak. Data yang digunakan berasal dari hasil studi pustaka, observasi dan wawancara pada objek penelitian.

\section{METODE PENELITIAN}




\section{Jenis Penelitian}

Penelitian ini dilakukan pada Travello Hotel Manado khususnya divisi room. Penelitian ini bersifat deskriptif yaitu dengan cara mengidentifikasi semua aktivitas yang ada di divisi room hotel Travello lalu mengklasifikasikan aktivitas tersebut menjadi aktivitas bernilai tambah dan tidak bernilai tambah. Aktivitas tidak bernilai tambah ini akan dieliminasi ataupun digabungkan dengan aktivitas yang lain yang sejenis sehingga biaya tidak bernilai tambah yang muncul dari aktivitas ini dapat direduksi jumlahnya.

\section{Prosedur Penelitian}

Menentukan rumusan masalah, merumuskan masalah penelitian, mencari informasi yang mendukung penelitian, menentukan metode penelitian, memberikan saran, membuat kesimpulan.

\section{Jenis dan Sumber Data}

Jenis data yang digunakan dalam penelitian ini adalah (1)Data kualitatif yaitu data yang disajikan secara deskriptif atau berbentuk uraian seperti sarana dan prasarana Hotel Travello Manado. (2)Data kuantitatif yaitu data yang disajikan dalam bentuk skala numeric atau angka. Data kuantitaf dalam penelitian ini yaitu data berupa laporan biaya divisi Room Hotel Travello Manado.dan bersumber dari laporan biaya tahun 2010

\section{Metode Pengumpulan Data}

Metode pengumpulan data yang akan dilakukan pada penelitian ini adalah: (1) Survey pendahuluan. Pada langkah ini akan dilakukan kunjungan awal ke perusahaan yaitu Hotel Travello Manado. Hal ini dilakukan untuk mengidentifikasi permasalahan yang ada di Hotel Travello Manado dan untuk memperoleh gambaran umum organisasi. Pemahaman dasar ini sangat penting guna mengembangkan analisa lebih lanjut, baik dalam studi kepustakaan maupun survey lapangan. (2) Wawancara yaitu teknik penelitian yang dilakukan dengan mengadakan wawancara atau tanya-jawab dengan pihak perusahaan yang ditunjuk atau pejabat berwenang yang ada hubungannya dengan data-data proses produksi dan biaya produksi yang dibahas dalam penelitian ini.

\section{Metode Analisis Data}

Metode analisis data yang dipakai pada penelitian ini yaitu menggunakan analisis deskriptif dimana data perusahaan yang telah terkumpul ini nantinya akan disusun, diolah, kemudian dianalisis dan dibandingkan dengan teori-teori yang telah ada selama ini. Dari hasil perbandingan itu, kemudian akan ditarik suatu kesimpulan. Langkah-langkah yang akan dilakukan dalam menganalisis data-data yang diperoleh adalah sebagai berikut: (1) Mengidentifikasi seluruh aktivitas yang dilakukan pada divisi room Hotel Travello Manado. (2) Menentukan cost driver dan besarnya biaya yang dikonsumsi oleh setiap aktivitas tersebut. (3) Melakukan analisis aktivitas untuk menentukan apakah aktivitas yang terjadi tergolong aktivitas bernilai tambah (value added activity) atau aktivitas tak bernilai tambah (non value added activity) dengan menggunakan indikator tiga kondisi yang harus dipenuhi secara simultan oleh aktivitas bernilai tambah. (4) Menentukan biaya dari aktivitas tak bernilai tambah yang telah diidentifikasi. (5) Menentukan alternatifalternatif apa saja yang dapat dilakukan untuk mereduksi atau bahkan memungkinkan untuk mengeliminasi aktivitas tak bernilai tambah tersebut dan untuk meningkatkan efisiensi dari aktivitas bernilai tambah yang terjadi sehingga efisiensi biaya yang diharapkan dapat tercapai. (6) Menarik kesimpulan dari analisis yang telah dilakukan dan memberikan saran yang nantinya mampu memberikan manfaat kepada perusahaan.

\section{HASIL PENELITIAN DAN PEMBAHASAN}

\section{Hasil Penelitian}


Data biaya divisi room selama tahun 2012 ini diperoleh dari bagian accounting hotel dimana biaya ini disusun untuk tujuan pembuatan laporan keuangan yang ditujukan bagi pihak manajemen hotel.

Tabel 4.1

Biaya-biaya Divisi Room Hotel Trvello Manado Tahun 2012

\begin{tabular}{|l|r|}
\hline \multicolumn{1}{|c|}{ Jenis Biaya } & \multicolumn{1}{c|}{$\begin{array}{c}\text { Jumlah Biaya } \\
\text { (Rp) }\end{array}$} \\
\hline Salaries & $1.460 .870 .777,00$ \\
Cleaning Supplies & $163.325 .720,00$ \\
Guest Supplies & $147.895 .785,00$ \\
Laundry \& Dry Cleaning & $112.198 .000,00$ \\
House Telephone \& Faximile & $65.951 .923,00$ \\
Printing \& Stationary & $80.750 .000,00$ \\
Papper Supplies & $6.950 .860,00$ \\
Guest \& Local Transportation & $29.623 .560,00$ \\
F\&B Guest Supplies & $1.170 .775 .908,00$ \\
Maintenance & $338.166 .400,00$ \\
\hline Total Biaya & $\mathbf{3 . 5 7 6 . 5 0 8 . 9 3 3 , 0 0}$ \\
\hline
\end{tabular}

\section{Analisis Cost Driver}

Untuk menelusuri biaya ke masing-masing unit aktivitas, diperlukan suatu penentuan cost driver. Dengan adanya suatu cost driver yang tepat maka biaya tersebut dapat dialokasikan secara tepat ke masingmasing unit aktivitas. Karena itu sebelum membebankan biaya-biaya divisi room ke unit aktivitas yang ada, perlu ditentukan terlebih dahulu cost driver tersebut. Setelah mengetahui ratio konsumsi pemicu biaya pada masing-masing unit aktivitas 2012 maka dilakukan pengalokasian biaya pada masing-masing unit aktivitas. Perincian alokasi biaya ke masing-masing unit aktivitas ditunjukkan pada table berikut.

Tabel 4.2

Rincian Alokasi Biaya Divisi Room Tahun 2012

\begin{tabular}{|c|c|c|c|c|}
\hline Jenis Biaya & Administrasi & Concierge & $\begin{array}{c}\text { Housekeeping \& } \\
\text { Laundry }\end{array}$ & Total \\
\hline Salaries & $536.646 .408,00$ & $357.764 .272,00$ & $566.460 .097,00$ & $1.460 .870 .777,00$ \\
\hline Cleaning Supplies & & & $163.325 .720,00$ & $163.325 .720,00$ \\
\hline Guest Supplies & & & $147.895 .785,00$ & $147.895 .785,00$ \\
\hline Laundry \& Dry Cleaning & & & $112.198 .000,00$ & 112.198.000,00 \\
\hline House Telephone \& Faximile & $32.975 .962,00$ & 19.785.577,00 & $13.190 .384,00$ & $65.951 .923,00$ \\
\hline Printing \& Stationary & $50.468 .750,00$ & $12.112 .500,00$ & $18.168 .750,00$ & $80.750 .000,00$ \\
\hline Paper Supplies & $4.678 .463,00$ & $1.002 .528,00$ & $1.269 .869,00$ & $6.950 .860,00$ \\
\hline Guest \& LocalTransportation & & $29.623 .560,00$ & & $29.623 .560,00$ \\
\hline F \& B Guest Supplies & & & $1.170 .775 .908,00$ & $1.170 .775 .908,00$ \\
\hline Maintenance & $37.574 .044,00$ & $75.148 .089,00$ & $225.444 .267,00$ & $338.166 .400,00$ \\
\hline Total Biaya & 662.343.627,00 & 495.436.526,00 & 2.418.728.780,00 & 3.576.508.933,00 \\
\hline
\end{tabular}

\section{Pengalokasian Biaya ke Aktivitas}

Setelah menentukan cost driver untuk masing-masing biaya dan alokasi biaya untuk tiap unit aktivitas yang ada maka pengalokasian besarnya biaya untuk masing-masing aktivitas dapat dilakukan. Pembebanan biaya ke tiap-tiap aktivitas ini ditentukan berdasarkan persentase dimana persentase tersebut diperoleh dengan cara membagi jumlah cost driver masing-masing aktivitas dengan jumlah cost driver tiap unit aktivitasnya 
Tabel 4.3

Biaya Aktivitas Divisi Room Hotel Travello Manado Tahun 2012

\begin{tabular}{|l|r|}
\hline \multicolumn{1}{|c|}{ Jenis Aktivitas } & \multicolumn{1}{|c|}{ Biaya Aktivitas } \\
\hline Unit Aktivitas Administrasi & $27.643 .321,33$ \\
\hline Supervise Front Office & $342.608 .464,33$ \\
Administrasi check-in,check-out,dan payment & $32.546 .985,82$ \\
Deposit Reservation & $33.726 .507,09$ \\
Room Numbering Block & $27.643 .321,33$ \\
Reservation Call Book \& Blockin & $27.643 .321,33$ \\
Reservation Confirmation & $33.726 .507,09$ \\
Arrangement Room Ocupied & \\
Unit Aktivitas Concierge & $55.291 .985,82$ \\
Membukakan pintu mobil tamu & $110.583 .971,65$ \\
Membawakan tas tamu dan mengantar tamu ke kamar & $50.236 .355,53$ \\
Melayani tamu dari dan ke bandara atau stasiun & $32.726 .507,09$ \\
Menangani masalah tamu yang pernah menginap & \\
Unit Aktivitas Housekeeping \& Laundry & $27.628 .169,64$ \\
\hline Supervisi housekeeping & $159.612 .244,53$ \\
Mempersiapkan kamar dan membersihkan kamar & $110.761 .580,99$ \\
Membersihkan area yang terletak di sekitar kamar & $82.934 .284,41$ \\
Melayani pencucian pakaian tamu & $82.934 .289,41$ \\
Menangani pencucian linen & $33.934 .289,41$ \\
Inspeksi kamar & $1.272 .182 .106,80$ \\
\hline
\end{tabular}

\section{Aktivitas Bernilai Tambah dan Aktivitas Tidak Bernilai Tambah}

Informasi yang diperoleh dari indikator analisis aktivitas tersebut dapat digunakan untuk menentukan aktivitas bernilai tambah dan tidak bernilai tambah. Value added activity (VA) nantinya akan dipertahankan oleh perusahaan sedangkan non value added activity (NVA) nantinya dapat digabung dengan aktivitas lain, direduksi volume aktivitasnya, ataupun dapat dieliminasi.

Aktivitas yang tergolong value added activity (VA) yaitu antara lain sebagai berikut:

1. Supervisi Front Office

2. Administrasi check-in, check-out, dan payment

3. Deposit Reservation

4. Reservation Call Book \& Blocking

5. Membukakan pintu mobil

6. Membawakan tas tamu dan mengantar tamu ke kamar

7. Melayani tamu dari dan ke bandara atau stasiun

8. Supervisi Housekeeping

9. Mempersiapkan kamar dan membersihkan kamar

10. Membersihkan area yang terletak di sekitar kamar

11. Melayani pencucian pakaian tamu

12. Melayani pencucian pakaian linen

13. Menangani pencucian linen

Sementara itu aktivitas lainnya yang tergolong non value added activity (NVA) adalah:

1. Room Number Block 


\section{Reservation Confirmation \\ 3. Arrangement Room Ocupied}

Pada tabel berikut ini akan ditampilkan jumlah biaya yang telah diklasifikasikan menjadi dua menurut analisis aktivitas yaitu value added activity (VA) dan non value added activity (NVA). Untuk selanjutnya, dari pengelompokan biaya ini nantinya akan dilakukan penggabungan, pengeliminasian, atau pereduksian beberapa aktivitas sehingga biaya tidak bernilai tambah yang muncul di divisi room Hotel Travello Manado ini dapat dikurangi.

Tabel 4.4

Biaya Value Added Activities dan Non Value Added Activities

\begin{tabular}{|l|r|r|r|}
\hline \multicolumn{1}{|c|}{ Jenis Aktivitas } & \multicolumn{1}{c|}{ VA } & \multicolumn{1}{c|}{ NVA } & \multicolumn{1}{c|}{ Total } \\
\hline Unit Aktivitas Administrasi & & & $104.200 .514,84$ \\
Supervise Front Office & $104.200 .514,84$ & & $302.596 .795,24$ \\
Administrasi check-in,check-out,dan payment & $302.596 .795,24$ & & $40.598 .656,85$ \\
Deposit Reservation & $40.598 .656,85$ & & $33.411 .061,82$ \\
Room Numbering Block & $38.721 .035,98$ & $33.411 .061,82$ & $38.721 .035,98$ \\
Reservation Call Book \& Blocking & & $53.286 .291,42$ & $53.286 .291,42$ \\
Reservation Confirmation & & $89.529 .270,84$ & $89.529 .270,84$ \\
Arrangement Room Ocupied & & & \\
Unit Aktivitas Concierge & $89.441 .068,00$ & & $89.441 .068,00$ \\
Membukakan pintu mobil tamu & $89.441 .068,00$ & & $89.441 .068,00$ \\
Membawakan tas dan mengantar tamu ke kamar & $918.985 .473,37$ & & $218.985 .473,37$ \\
Melayani tamu dari dan ke bandara atau stasiun & & $97.568 .916,63$ \\
Menangani masalah tamu yang pernah menginap & $139.385 .710,00$ & & \\
Unit Aktivitas Housekeeping \& Laundry & $1.611 .764 .529,00$ & & $139.385 .710,00$ \\
Supervisi housekeeping & $216.925 .832,7$ & & $1.611 .764 .529,00$ \\
Mempersiapkan kamar dan membersihkan kamar & $235.120 .777,1$ & & $216.925 .832,7$ \\
Membersihkan area yang terletak di sekitar kamar & $215.531 .930,8$ & & $235.120 .777,1$ \\
Melayani pencucian pakaian tamu & $3.400 .282308,92$ & $176.226 .624,08$ & $3.576 .508 .933,00$ \\
Menangani pencucian linen & & & \\
\hline \multicolumn{1}{|c|}{ TOTAL } & & \\
& & & \\
\hline
\end{tabular}

Dari hasil analisa sebelumnya nampak bahwa ada beberapa aktivitas yang dapat digabungkan dengan aktivitas lain yang sejenis, direduksi volume aktivitasnya, atau bahkan ada yang perlu untuk dieliminasi. Aktivitas tersebut antara lain:

1. Melalui eliminasi aktivitas Room Numbering Block sebesar $100 \%$, maka biaya aktivitas ini dapat berkurang sebesar Rp. 33.411.061,82

2. Aktivitas reservation confirmation juga dieliminasi sebesar $100 \%$ dan hal ini berarti biaya yang diserap oleh aktivitas ini juga dapat dikurangi sebesar Rp. 53.286.291,42

3. Aktivitas arrangement room occupied akan dieliminasi sebesar $100 \%$ akibatnya akan terjadi pengurangan biaya untuk aktivitas ini sebesar Rp. 89.529.270,84

\section{Pembahasan}

Pengurangan biaya ini perlu dilakukan Hotel Travello Manado seiring dengan munculnya beberapa aktivitas tidak bernilai tambah di hotel tersebut karena aktivitas tersebut nantinya hanya berdampak pada 
munculnya biaya yang tidak bernilai tambah yang tentu saja merugikan bagi pihak Hotel Travello Manado. Dari hasil analisa sebelumnya nampak bahwa ada beberapa aktivitas yang dapat digabungkan dengan aktivitas lain yang sejenis, direduksi volume aktivitasnya, atau bahkan ada yang perlu untuk dieliminasi . Aktivitas tersebut antara lain:

1. Room Numbering Block

Aktivitas ini adalah aktivitas member tanda untuk nomor kamar yang ditempati oleh tamu dan aktivitas ini hampir sama dengan aktivitas reservation call book \& blocking sehingga aktivitas ini tidak bernilai tambah, oleh karena itu aktivitas ini dapat dieliminasi karena merupakan bentuk pengulangan dari aktivitas reservation call book \& blocking sehingga biayanya dapat dieliminasi $100 \%$. Aktivitas ini termasuk dalam aktivitas membuat skedul.

2. Reservation Confirmation

Aktivitas ini adalah aktivitas untuk melakukan konfirmasi ulang kepada tamu yang akan menginap di hotel. Aktivitas ini juga dapat dieliminasi karena sama dengan aktivitas reservation call book \& blocking sehingga aktivitas reservation confirmation ini hanya menghasilkan biaya tidak bernilai tambah. Dengan adanya pengeliminasian aktivitas ini maka biaya yang muncul juga dieliminasi sebanyak $100 \%$. Aktivitas ini termasuk dalam aktivitas membuat skedul.

3. Arrangement Room Ocupied

Merupakan aktivitas untuk mengatur kamar setelah tamu tiba di hotel. Aktivitas ini dieliminasi karena jika pihak hotel telah memastikan dengan jelas kepada pihak pemesan kamar mengenai jumlah kamar yang akan dihuni oleh tamu pada saat tamu tersebut melakukan reservasi maka pihak hotel dapat memperoleh informasi mengenai jumlah kamar yang akan disediakan untuk tamu yang memesan kamar sehingga aktivitas ini tidak dapat diperlukan lagi dan aktivitas ini dapat dieliminasi sebesar 100\%. Aktivitas ini termasuk dalam aktivitas membuat skedul.

Pengurangan biaya untuk beberapa aktivitas tidak bernilai tambah tersebut dapat ditunjukkan pada tabel 4.5 berikut.

Tabel 4.5

Biaya Aktivitas Tidak Bernilai Tambah Divisi Room Hotel Travello Manado Tahun 2012 Setelah Cost Reduction

\begin{tabular}{|c|c|c|c|}
\hline $\begin{array}{c}\text { Aktivitas Tidak Bernilai } \\
\text { Tambah } \\
\text { (NVA) }\end{array}$ & Biaya Aktivitas & $\begin{array}{c}\text { \% Cost } \\
\text { Reduction }\end{array}$ & Besar Cost Reduction \\
\hline Room Number Block & $33.411 .061,82$ & $100 \%$ & $33.411 .061,82$ \\
Reservation Confirmation & $53.286 .291,42$ & $100 \%$ & $53.286 .291,42$ \\
Arrangement Room Ocupied & $89.529 .270,84$ & $100 \%$ & $89.529 .270,84$ \\
\hline \multicolumn{1}{|c|}{ Total } & $176.226 .624,08$ & & $176.226 .624,08$ \\
\hline
\end{tabular}

Dari pengeliminasian aktivitas tidak bernilai tambah tersebut, maka biaya aktivitas yang timbul di divisi room Hotel Travello Manado ini tentu saja akan berkurang. Total pengurangan biaya ini dapat dilihat pada tabel 4.21 berikut

Tabel 4.6

Biaya Aktivitas Divisi Room Hotel Travello Manado Tahun 2012 Setelah Cost Reduction

\begin{tabular}{|l|c|}
\hline \multicolumn{1}{|c|}{ Jenis Aktivitas } & Biaya Aktivitas \\
\hline Unit Aktivitas Administrasi & \\
\hline
\end{tabular}




\begin{tabular}{|l|r|}
\hline Supervisi Front Office & $104.200 .514,84$ \\
Administrasi check-in,check-out,dan payment & $302.596 .795,24$ \\
Deposit Reservation & $40.598 .656,85$ \\
Reservation Call Book \& Blocking & $38.721 .035,98$ \\
Unit Aktivitas Concierge & \\
\hline Membukakan pintu mobil tamu & $89.441 .068,00$ \\
Membawakan tas tamu dan mengantar tamu ke kamar & $89.441 .068,00$ \\
Melayani tamu dari dan ke bandara atau stasiun & $218.985 .473,37$ \\
Menangani masalah tamu yang pernah menginap & $97.568 .916,63$ \\
Unit Aktivitas Housekeeping \& Laundry & \\
Supervisi housekeeping & $139.385 .710,00$ \\
Mempersiapkan kamar dan membersihkan kamar & $1.611 .764 .529,00$ \\
Membersihkan area yang terletak di sekitar kamar & $216.925 .832,7$ \\
Melayani pencucian pakaian tamu & $235.120 .777,1$ \\
Menangani pencucian linen & $215.531 .930,8$ \\
\hline \multicolumn{2}{|c|}{ Total } \\
\hline
\end{tabular}

Dengan menggunakan Activity-Based Management maka total biaya di divisi room Hotel Travello Manado dapat berkurang sebanyak Rp. 176.226.624,08 yaitu dari Rp. 3.576.508.933 menjadi Rp 3.400.282308,92 dan memberikan informasi kepada pihak hotel agar dapat meningkatkan efisiensi biaya ditahun-tahun berikutnya.

\section{PENUTUP}

\section{Kesimpulan}

Dalam aktivitasnya Hotel Travello Manado belum menerapkan Activity Based Management sebagai dasar aktivitasnya sehingga masih ada aktivitas yang tidak bernilai tambah yang tidak dihilangkan oleh perusahaan sehingga masih ada penggunaan sumber daya yang tidak memberi value added bagi perusahaan. Pada divisi room terdapat beberapa aktivitas tidak bernilai tambah yang menyebabkan timbulnya biaya tidak bernilai tambah yaitu sebesar Rp. 176.226.624,08 setelah dilakukan manajemen aktivitas maka biaya tidak bernilai tambah tersebut akhirnya dapat direduksi dan menjadi perencanaan untuk pencapaian efisiensi biaya ditahun berikutnya. maka dapat disimpulkan bahwa penerapan activity-based management (ABM) sangat layak untuk diterapkan karena dengan penerapan metode tersebut terjadi efisiensi biaya pada Hotel Travello Manado sehingga hal ini akan memberi keuntungan bagi pihak hotel tanpa mengurangi jasa yang diterima oleh pelanggan.

\section{Saran}

Berdasarkan kesimpulan tersebut, maka saran-saran yang dapat diberikan kepada pihak Hotel Travello Manado, yaitu:

1. Hotel Travello Manado perlu meninjau kembali aktivitas-aktivitas yang ada. Hal ini dapat dilakukan salah satunya dengan cara menerapkan Activity Based Management dalam perusahaan sehingga tidak ada aktivitas yang tidak bernilai tambah dalam operasi produksi perusahaan karena aktivitas tidak bernilai tambah ini akan menimbulkan biaya tidak bernilai tambah.

2. Beberapa tindakan alternatif yang dapat dilakukan oleh manajemen Hotel Travello Manado sebagai upaya untuk menggabungkan aktivitas sejenis, mereduksi atau bahkan mengeliminasi aktivitas tidak bernilai tambah di divisi room agar tercipta efisiensi biaya, yaitu:

a. Mengeliminasi aktivitas room number block dan reservation confirmation karena merupakan pengulangan aktivitas reservation call book \& blocking. 
b. Mengeliminasi aktivitas arrangement room ocupied karena jika pihak hotel telah memastikan dengan jelas kepada pihak pemesan kamar mengenai jumlah kamar yang akan dihuni oleh tamu pada saat tamu tersebut melakukan reservasi maka pihak hotel dapat memperoleh informasi mengenai jumlah kamar yang akan disediakan untuk tamu yang memesan kamar sehingga aktivitas ini tidak diperlukan.

\section{DAFTAR PUSTAKA}

Blocher., Stout., Cokins. 2011. Manajemen Biaya. Edisi 5.Terjemahan. Salemba Empat. Jakarta.

Brimson, James A., Antos, John 2008. An Activity-Based Costing Approach. John Wiley \&Sons, Inc. New York.

Hansen, Don R.,Mowen, Maryane M. 2009. Management Accounting.Edisi 8.Terjemahan. Salemba Empat. Jakarta.

Hilton, Ronald W., Maher., Selto, F.H. 2006 Cost Managerial: A Strategic for Busines Decision. Third Edition. McGraw-Hill, Inc. New York.

Horngren, Charles T., Datar, Srikant,M., Foster, George. 2008. Cost Accounting, A Managerial Emphasis. Twelfth Edition.International Edition.Prentice Hall Inc.New Jersey

Miller, Michael. 2008. Implementing Activity-Based Management in Daily Operations. John Wiley dan Sons Inc. New York.

Mulyadi. 2005. Akuntansi Manajemen. Salemba Empat. Jakarta.

Rudianto. 2009. Pengantar Akuntansi. Erlangga. Jakarta.

Supriyono. 2008. Manajemen Biaya: Suatu Reformasi Pengelolaan Bisnis. Cetakan Keempat. Rajagravindo Persada.Yogyakarta.

Tunggal, Amin Widjaja. 2010. Memahami Konsep Activity Based Management dan Activity-Based Costing. Harvarindo. Jakarta. 